\title{
Effects of compound $K$, an enteric microbiome metabolite of ginseng, in the treatment of inflammation associated colon cancer
}

\author{
HAIQIANG YAO $^{1-3}$, JIN-YI WAN ${ }^{1-3}$, JINXIANG ZENG ${ }^{2,3}$, WEI-HUA HUANG ${ }^{2,3}$, CLARA SAVA-SEGAL ${ }^{2,3}$, \\ LINGRU LI $^{1}$, XIN NIU ${ }^{1}$, QI WANG ${ }^{1}$, CHONG-ZHI WANG $^{2,3}$ and CHUN-SU YUAN ${ }^{2-4}$ \\ ${ }^{1}$ School of Basic Medical Science, Beijing University of Chinese Medicine, Beijing 100029, P.R. China; \\ ${ }^{2}$ Tang Center for Herbal Medicine Research; ${ }^{3}$ Department of Anesthesia and Critical Care; \\ ${ }^{4}$ Comprehensive Cancer Center, University of Chicago, Chicago, IL 60637, USA
}

Received October 27, 2017; Accepted March 16, 2018

DOI: $10.3892 / \mathrm{ol} .2018 .8414$

\begin{abstract}
Ginsenoside Rb1, a major component of different ginseng species, can be bioconverted into compound $\mathrm{K}$ by gut microbiota, and the latter possess much stronger cancer chemopreventive potential. However, while the initiation and progression of colorectal cancer is closely associated with gut inflammation, to date, the effects of compound $\mathrm{K}$ on inflammation-linked cancer chemoprevention have not been reported. In the present study, liquid chromatography quadrupole time-of-flight mass spectrometry analysis was applied to evaluate the biotransformation of Rb1 in American ginseng by human enteric microflora. The in vitro inhibitory effects of Rb1 and compound $\mathrm{K}$ were compared using the HCT-116 and HT-19 human colorectal cancer cell lines by a MTS assay. Cell cycle and cell apoptosis were assayed using flow cytometry. Using ELISA, the anti-inflammatory effects of Rb1 and compound $\mathrm{K}$ were compared for their inhibition of interleukin-8 secretion in HT-29 cells, induced by lipopolysaccharide. The results revealed that compound $\mathrm{K}$ is the major intestinal microbiome metabolite of Rb1. When compared with $\mathrm{Rb} 1$, compound $\mathrm{K}$ had significantly stronger anti-proliferative effects in HCT-116 and HT-29 cell lines $(\mathrm{P}<0.01)$. Compound K significantly arrested HCT-116 and HT-29 cells in the G1 phase, and induced cell apoptosis $(\mathrm{P}<0.01)$. By contrast, Rb1 did not markedly influence the cell cycle or apoptosis. Furthermore, compound K exerted significant anti-inflammatory effects even at low concentrations $(\mathrm{P}<0.05)$,
\end{abstract}

Correspondence to: Professor Xin Niu or Professor Qi Wang, School of Basic Medical Science, Beijing University of Chinese Medicine, 11 N 3rd Ring Road E, Chaoyang, Beijing 100029, P.R. China

E-mail: niux1@vip.sina.com

E-mail: wangqi710@126.com

Key words: ginsenoside Rb1, compound K, liquid chromatography quadrupole time-of-flight mass spectrometry, colorectal cancer, HCT-116 cancer cell, HT-29 cancer cells, anti-proliferation, anti-inflammation, apoptosis, cell cycle while Rb1 did not have any distinct effects. The data obtained from the present study demonstrated that compound $\mathrm{K}$, an intestinal microbiome metabolite of $\mathrm{Rbl}$, may have a potential clinical value in the prevention of inflammatory-associated colorectal cancer.

\section{Introduction}

Ginseng is a popular herbal medicine worldwide. American ginseng (Panax quinquefolius L.), belonging to Araliaceae family, is one of the most commonly used botanicals in the United States. Asian ginseng (Panax ginseng C. A. Meyer), another well-known species in the same family, has a long history of use in East Asian countries with favorable health benefits (1-3). Previous reports suggested that long-term ginseng consumption is associated with a decreased risk for multiple human cancers $(4,5)$. It is generally believed that the active constituents in both ginsengs are a group of triterpene glycosides, referred to as ginseng saponins or ginsenosides, in which more than 100 have been isolated from botanical sources (6-8). It has been shown that ginsenoside Rb1 acts as a major protopanaxadiol (PPD) group saponin (9).

Like many other herbal medicines, ginseng is taken orally. After ginseng ingestion, these natural ginsenosides are inevitably exposed to gut microflora in the gastrointestinal tract, and these compounds are biotransformed into active metabolites by the enteric microbiome before being absorbed $(10,11)$. These metabolites are mainly involved in the deglycosylation reaction via stepwise cleavage of the sugar moieties, ultimately producing their pharmacological effects $(10,12,13)$.

Based on our previous studies, via enteric microbiota activities, ginsenoside Rb1 could be converted into compound $\mathrm{K}$, a major bioactive metabolite absorbed into the systemic circulation $(13,14)$. Our former research has demonstrated the significant anti-proliferative and pro-apoptotic effects of compound $\mathrm{K}$ using two selected human colorectal cancer cell lines, HCT-116 and SW-480 (15). However, the comparison between ginsenoside $\mathrm{Rb} 1$ and compound $\mathrm{K}$ on the inflammatory-linked colorectal cancer has not been reported.

HT-29 is another human colorectal cancer cell line. These HT-29 cells are not only resistant to chemotherapeutic agents, but also secrete inflammatory cytokine when induced by 
lipopolysaccharide (LPS). Thus, the HT-29 cell line could serve a good model for inflammatory-linked colon cancer studies. In this project, in addition to HCT-116, HT-29 cells were used to evaluate whether compound $\mathrm{K}$ possesses anticancer effects on chemo-resistant cell lines. The related mechanisms of action were explored. Further, its inflammatory-linked chemopreventive effects were investigated.

\section{Materials and methods}

Reagents and materials. Reference compounds including ginsenoside Rb1 and compound $\mathrm{K}$ were obtained from Indofine Chemical Company (Somerville, NJ, USA) and ChromaDex Inc. (Irvine, CA, USA), respectively, whose purities were more than $98 \%$ determined by HPLC-DAD. General anaerobic medium (GAM) was obtained from Kayon Biological Technology Co. Ltd. (Shanghai, China). Acetonitrile (ACN) and formic acid of HPLC grade were from Merck KGaA (Darmstadt, Germany). Deionized water (18 M $\Omega-\mathrm{cm})$ was supplied with a Milli-Q water system (Millipore, Milford, MA, USA). Trypsin, McCoy's 5A, and phosphate-buffered saline were obtained from Mediatech, Inc. (Herndon, VA, USA). Penicillin and streptomycin were obtained from Sigma-Aldrich (St. Louis, MO, USA). An MTS assay kit, CellTiter 96 Aqueous Solution Cell Proliferation Assay, was obtained from Promega (Madison, WI, USA). A FITC-Annexin V apoptosis detection kit was obtained from BD Biosciences (Rockville, MD, USA). PI/RNase staining buffer was obtained from BD Biosciences Pharmingen (San Diego, CA, USA). All cell culture plasticware were obtained from Falcon Labware (Franklin Lakes, NJ, USA) and Techno Plastic Products (Trasadingen, Switzerland).

Plant materials and extraction. The air-dried roots of American ginseng (P. quinquefolius L.) were purchased from Roland Ginseng, LLC (Wausau, WI, USA). The voucher samples were deposited at the Tang Center for Herbal Medicine Research at the University of Chicago (Chicago, IL, USA). The powdered American ginseng was extracted with $70 \%$ ethanol twice by the heat-reflux method. The combined filtrate was condensed under vacuum and then lyophilized to yield dried American ginseng extract (AGE).

Biotransformation of AGE by human fecal microflora. The present study protocol was approved by the Institutional Review Board at the University of Chicago; patients provided oral consent for sample collection. Fecal samples were collected from six healthy adult volunteers (non-smokers without antibiotic consumption more than 6 months before the experiment) between September 2013 and September 2015. All the fresh fecal samples were mixed. The $5 \mathrm{~g}$ of mixed feces were homogenized with $30 \mathrm{ml}$ of cold physiological saline and filtered through gauze to obtain the resulting fecal liquid. One microliter of fecal liquid was mixed with $8 \mathrm{ml}$ of GAM containing $3 \mathrm{mg}$ of AGE. They were anaerobically incubated at $37^{\circ} \mathrm{C}$ for $24 \mathrm{~h}$. The reaction mixture was extracted with water-saturated n-butanol for three times. Then the combined n-butanol solution was dried under the nitrogen stream and re-dissolved in methanol. The solution was centrifuged at $13,000 \mathrm{x}$ g for $10 \mathrm{~min}$ before analysis.
LC-Q-TOF-MS analysis. Chromatographic analysis was performed on an Agilent 1290 LC instrument (Agilent Technologies, GmbH, Waldbronn, Germany) with a binary pump, an online degasser, an auto plate-sampler, and a thermostatically controlled column compartment. The separation was carried out on an Agilent C18 column (4.6×250 mm, $5 \mu \mathrm{m})$. A gradient mobile phase system of water $(0.1 \%$ formic acid, eluent A) and ACN (0.1\% formic acid, eluent B) was applied as follows: $79 \% \mathrm{~A}$ and $21 \% \mathrm{~B}(0 \mathrm{~min}), 79 \% \mathrm{~A}$ and $21 \% \mathrm{~B}$ (16 min), 70\% $\mathrm{A}$ and $30 \% \mathrm{~B}(27 \mathrm{~min}), 55 \% \mathrm{~A}$ and $45 \% \mathrm{~B}$ (34 min), 25\% A and 75\% B (40 min), 100\% B (46 min). The flow rate was set at $1 \mathrm{ml} / \mathrm{min}$ and the injected sample was $2 \mu 1$.

Detection was performed by a 6520 Q-TOF mass spectrometer (Agilent Technologies, Santa Clara, CA, USA) with a dual electrospray ionization (ESI) source. The mass parameters for detection were optimized in the following: Drying gas flow rate, $10 \mathrm{l} / \mathrm{min}$; drying gas temperature, $320^{\circ} \mathrm{C}$; nebulizer, 35 psig; capillary, $3500 \mathrm{~V}$; OCT RFV, $750 \mathrm{~V}$; and fragmentor voltage, $120 \mathrm{~V}$. The range $\mathrm{m} / \mathrm{z}$ from 100 to 2,000 were recorded in the negative mode. Agilent MassHunter Acquisition Software version B.04.00 (Agilent Technologies) was applied to monitor the operations and data acquisitions.

Cell culture. The human colorectal cancer cell line HT-29 was obtained from the American Type Tissue Collection (Rockville, MD, USA). The cell line was maintained in McCoy's 5A which was supplemented with $10 \% \mathrm{FBS}$, penicillin (100 IU/ml) and streptomycin $(100 \mu \mathrm{g} / \mathrm{ml})$. The HT-29 cells were incubated in a humidified atmosphere with $5 \% \mathrm{CO}_{2}$ at $37^{\circ} \mathrm{C}$ and subcultured every two days.

Cell proliferation analysis. Ginsenoside $\mathrm{Rb} 1$ and compound $\mathrm{K}$ were dissolved in DMSO and stored in small aliquots at $-20^{\circ} \mathrm{C}$ prior to use. The HT-29 cells were seeded in 96-well plates at a density of 5,000 cells/well, after incubating for $24 \mathrm{~h}$ the cells were treated with different concentrations of Rb1 and compound $\mathrm{K}$, and the final concentration of DMSO was $0.5 \%$. Controls were exposed to culture medium containing $0.5 \%$ DMSO without drugs. All experiments were performed in triplicate and repeated for 3 times. Following the indicated incubation durations, cell proliferation was detected by means of the MTS assay according to the manufacturer's instructions. Briefly, the medium was replaced with $100 \mu \mathrm{l}$ of fresh medium and $20 \mu \mathrm{l}$ of MTS reagent (CellTiter 96 Aqueous Solution) in each well, and the plate was returned to the incubator for 1-2 $\mathrm{h}$, then $60 \mu \mathrm{l}$ aliquot of medium from each well was transferred to an ELISA 96-well plate and its absorbance at $490 \mathrm{~nm}$ was read by an automated microplate reader (Epoch; Bio-Tek Instruments, Winooski, VT, USA). Since 0.5\% DMSO did not influence the proliferation of the cell line, results were expressed as percent of control (DMSO vehicle set at 100\%).

Cell cycle and apoptosis analysis using flow cytometry. Cells were seeded in 24-well tissue culture plates. On the second day, the medium was replaced with experimental compounds added. Cells were cultured for $48 \mathrm{~h}$ before they were harvested. These cells were fixed gently with $80 \%$ ethanol in a freezer for $2 \mathrm{~h}$ and were then treated with $0.25 \%$ Triton $\mathrm{X}-100$ for $5 \mathrm{~min}$ on an ice bath. Cells were resuspended in $300 \mu \mathrm{l}$ of PBS containing $40 \mu \mathrm{g} / \mathrm{ml}$ propidium iodide (PI) and $0.1 \mathrm{mg} / \mathrm{ml}$ 
RNase. Then the cells were incubated in dark for $20 \mathrm{~min}$ at room temperature, and cell cycle analysis was performed using a LSRII flow cytometer (BD Biosciences, Franklin Lakes, NJ) and FlowJo 10.1.0 software (Tree Star, Ashland, OR, USA). For each measurement, at least 10,000 cells were counted.

The apoptosis assay was performed according to the following steps. After treatment for $48 \mathrm{~h}$, the culture medium containing floating cells was collected, and trypsin was added to detach the adherent cells. Then the firstly collected culture medium was added back to inactivate the trypsin. After being pipetted gently, the cells were centrifuged at 2,000 rpm for $5 \mathrm{~min}$. The supernatant was decanted and cells were stained with FITC-Annexin V and PI according to the manufacturer's instructions. Untreated cells served as control. The cells were analyzed immediately after staining using flow cytometry. For each measurement, at least 20,000 cells were counted.

Reverse transcription-quantitative polymerase chain reaction $(R T-q P C R)$. HCT-116 cells were treated with $30 \mu \mathrm{M}$ of compound $\mathrm{K}$ for 6,12 or $24 \mathrm{~h}$. Total RNA was isolated using the RNAeasy kit (Qiagen, Hilden, Germany). First strand cDNA was synthesized using a SuperScript II First-Strand Synthesis System (Invitrogen, Carlsbad, CA). RT-qPCR was performed using the following primers $\left(5^{\prime}-3^{\prime}\right)$ : CDKN1A forward, CCT CATCCCGTGTTCTCCTTT, and reverse, GTACCACCC AGCGGACAAGT; CDK6 forward, TGGAGACCTTCGAGC ACC and reverse, CACTCCAGGCTCTGGAACTT; CCND1 forward ACGAAGGTCTGCGCGTGTT and reverse, CCG CTGGCCATGAACTACCT; CCNE1 forward, ATCAGC ACTTTCTTGAGCAACA and reverse, TTGTGCCAA GTAAAAGGTCTCC; TP53 forward, TGGCATTTGCAC CTACCTCAC, and reverse, AACTCCCTCTACCTAACC AGC; BAX, forward, GAGAGGTCTTTTTCCGAGTGG, and reverse, GCTGGCAAAGTAGAAAAGGGC; BCL2 forward, GGCCTTCTTTGAGTTCGGTG and reverse, ACA GGGCGATGTTGTCCAC; GAPDH forward, TGCACCACC AACTGCTTAGC and reverse, GGCATGGACTGTGGT CATGAG. GAPDH was used as an internal reference gene to normalize the expression of selected genes. Relative gene expression levels were determined using the $2^{-\Delta \Delta \mathrm{Cq}}$ method.

Inflammatory cytokine IL-8 secretion test. The HT-29 cells were seeded in 96-well plates and cultured for $48 \mathrm{~h}$. Different concentrations of Rb1 or compound K plus $100 \mathrm{ng} / \mathrm{ml}$ LPS added in the medium were set as the experimental group, while for control group there were only $100 \mathrm{ng} / \mathrm{ml}$ LPS and medium without any drugs. After incubation for $6 \mathrm{~h}$, the culture medium was collected, the secreted IL-8 was quantified by enzyme-linked immunosorbent assay (ELISA; Thermo Fisher Scientific, MA, USA), and anti-inflammatory activities were calculated.

Statistical analysis. Results are expressed as the mean \pm standard error, and experiments were performed in triplicate with 3 repeats. A Student's t-test and one-way analysis of variance with Tukey's post hoc test were performed to evaluate the significance of the differences between ginseng treatment and model groups. All statistical analyses were performed using SPSS version 22.0 (IBM Corp., Armonk, NY, USA). $\mathrm{P}<0.05$ was considered to indicate a statistically significant difference.

\section{Results}

The biotransformation of ginsenoside Rbl to compound $K$ by human enteric microflora. As shown in Fig. 1A, the typical total ion chromatography (TIC) of AGE is displayed in the negative ion mode. Using LC-Q-TOF-MS analysis, there was a total of 20 major ginseng saponins detected in the extract, and ginsenoside $\mathrm{Rb}$ l occupied the highest peak as the primary constituent. When the ginseng extract was incubated with human gut microflora for $24 \mathrm{~h}$, the peak of ginsenoside Rb1 was significantly decreased (Fig. 1B) in comparison with the original un-transformed sample. Compound $\mathrm{K}$ was identified as one of its main metabolites. The extracted ion chromatograms (EICs) of ginsenoside Rb1 and compound $\mathrm{K}$ are further confirmed from the intricate matrix of the biotransformed ginseng sample with a narrow mass window of $0.01 \mathrm{Da}$ in Fig. 1C and D, respectively. Fig. 1E and F show the data of ginsenoside $\mathrm{Rb} 1$ and compound $\mathrm{K}$ in the negative MS/MS ion mode. Since formic acid was added in the mobile phase, ginsenoside $\mathrm{Rb} 1$, the typical solvent adduct ion $[\mathrm{M}+\mathrm{HCOO}]^{-}$ $(\mathrm{m} / \mathrm{z} 1153.6032)$ and deprotonated molecular ion $[\mathrm{M}-\mathrm{H}]^{-}(\mathrm{m} / \mathrm{z}$ 1107.5926), as well as a series of successive losses of $162 \mathrm{Da}$ corresponding to glucose moiety were observed. Compound $\mathrm{K}$ has similar MS/MS behavior to [M+HCOO] ${ }^{-}(\mathrm{m} / \mathrm{z}$ 667.4423), $[\mathrm{M}-\mathrm{H}]^{-}(\mathrm{m} / \mathrm{z} \text { 621.4341), and [M-H-Glc] }]^{-}(\mathrm{m} / \mathrm{z} 459.3857)$ in the negative ion mode. Combined with the metabolites detected in this study, the metabolic pathways of Rb1 by human intestinal microflora are proposed in Fig. 1G.

The major route was initiated when ginsenoside $\mathrm{Rb} 1$ eliminated C-3 and C-20 glucoses to form ginsenoside F2, and was further converted into compound $\mathrm{K}$ by a C-3 glucose elimination, which is easily absorbed into the circulation. Another route was produced from ginsenoside Rb1 to gypenoside XVII by the glucose elimination at C-3, and thus to ginsenoside F2 and compound $\mathrm{K}$. In addition, ginsenoside Rb1 selectively eliminated the $\mathrm{C}-20$ glucose chain to generate ginsenoside $\mathrm{Rd}$ and Rg3. Fig. 1 also indicates that compound $\mathrm{K}$ is the major metabolite of ginsenoside Rb1 by human gut microflora.

Effects of Rbl and compound $K$ on colorectal cancer cell proliferation. The anti-proliferative effects of the ginsenoside $\mathrm{Rb} 1$ and compound $\mathrm{K}$ were evaluated using two human colorectal cancer cell lines, HCT-116 and HT-29. Fig. 2A shows the concentration-related anti-proliferative effects of compound K on HCT-116 colorectal cancer cells after a $6 \mathrm{~h}$ treatment, and similar results were observed in HT-29 cells (Fig. 2B).

The effects of compound K on HCT-116 and HT-29 are illustrated in Fig. 2E and F, respectively. As shown in the figure, at the concentration of $60 \mu \mathrm{M}$, compound $\mathrm{K}$ exerted prominent growth suppression in HCT-116 cells. After treatment at 24, 48 and $72 \mathrm{~h}$, compound K inhibited HCT-116 cell growth by $75.81 \pm 3.65,98.01 \pm 0.41$ and $100 \%$, respectively (both $\mathrm{P}<0.01$ ), indicating a time-related effect manner. Similar results were observed in HT-29 cells (Fig. 2F). In contrast, Rb1 did not obviously inhibit cell growth at concentrations of $0-500 \mu \mathrm{M}$ for HCT-116 and HT-29 (Fig. 2C and D).

Effects of Rbl and compound $K$ on cell cycle. Antiproliferative evaluation suggested that compound $\mathrm{K}$ was 


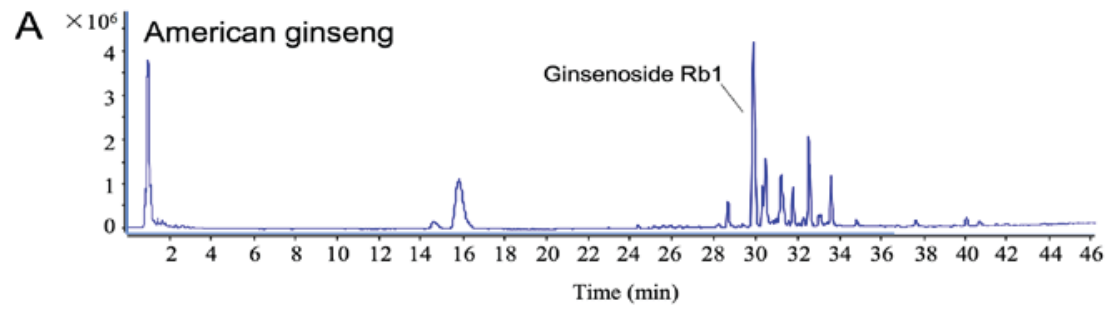

$\mathrm{B} \times 10$
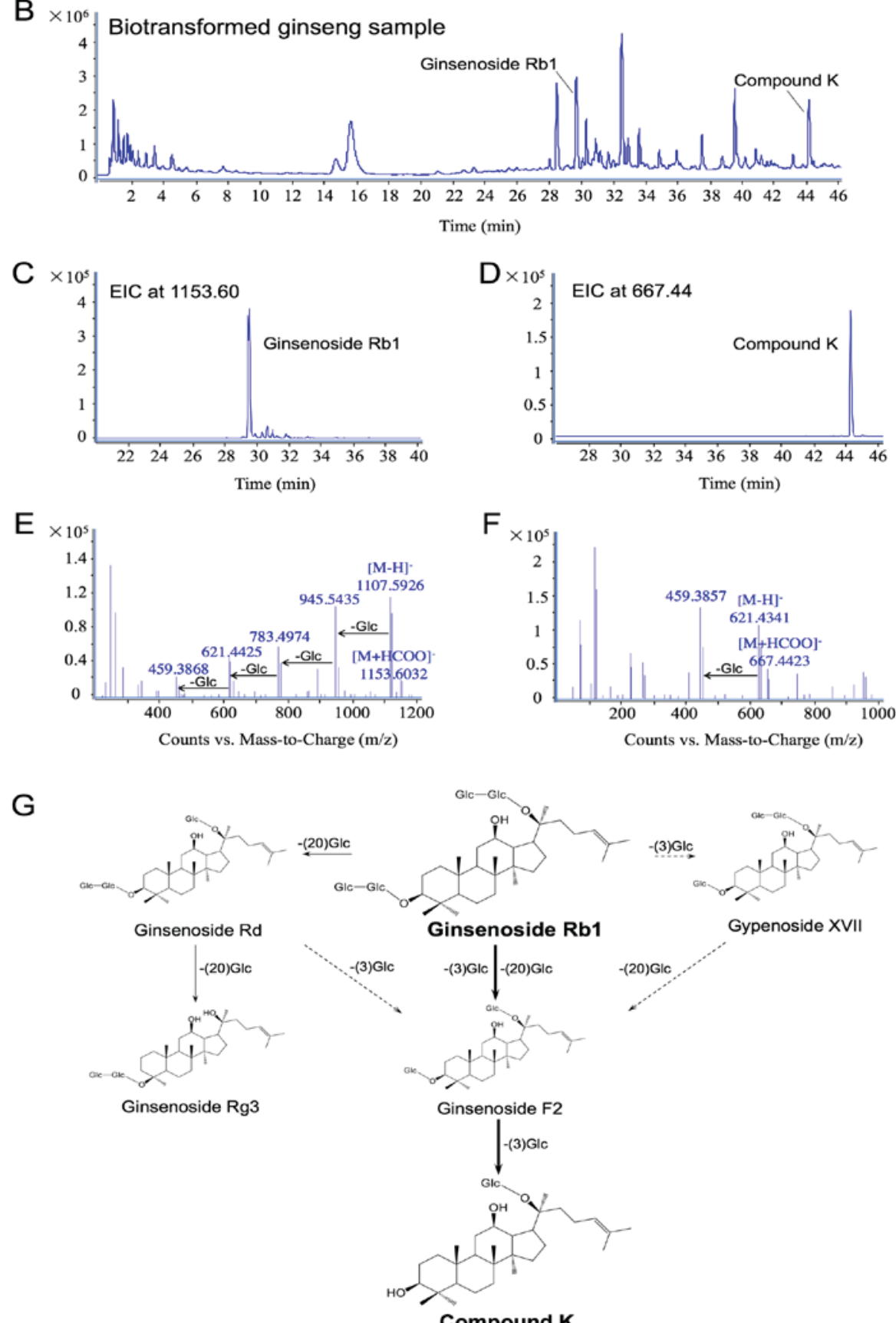

Figure 1. Biotransformation of ginsenoside Rb1 to compound $\mathrm{K}$ by human enteric microflora. Liquid chromatography quadruple time-of-flight-MS data are shown in (A-F). (A) Total ion chromatography of American ginseng extract, in which Rb1 occupies the highest peak. (B) TIC of biotransformed American ginseng sample, in which compound $\mathrm{K}$ is one of the identified main metabolites. (C) EIC of Rb1 in biotransformed sample with a narrow window of $0.01 \mathrm{Da}$. (D) EIC of compound K with a narrow window of $0.01 \mathrm{Da}$. (E) MS/MS spectra of Rb1, and (F) MS/MS spectra of compound K. (G) Proposed metabolic pathways via gut microflora from Rb1 to compound K. EIC, extracted ion chromatogram; MS, mass spectrometry; TIC, total ion chromatography.

active in inhibiting the human colorectal cancer cell growth. To explore whether this was because of cell cycle arrest at a specific phase, cell cycle profile was assayed using flow cytometry. As shown in Fig. 3, the effects of compound K on the cell cycle profile were observed at concentrations as low as $40 \mu \mathrm{M}$. Treatment of HCT-116 cells with 40 and $50 \mu \mathrm{M}$ 
A

HCT-116

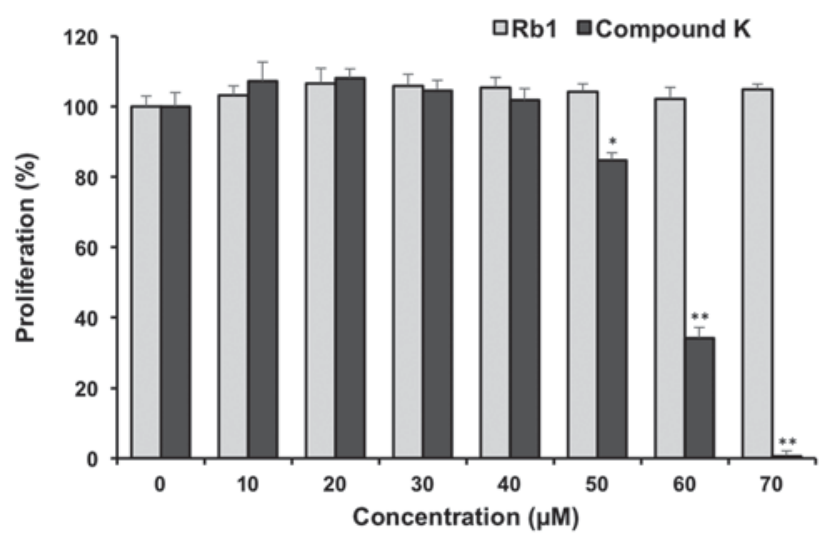

Rb1
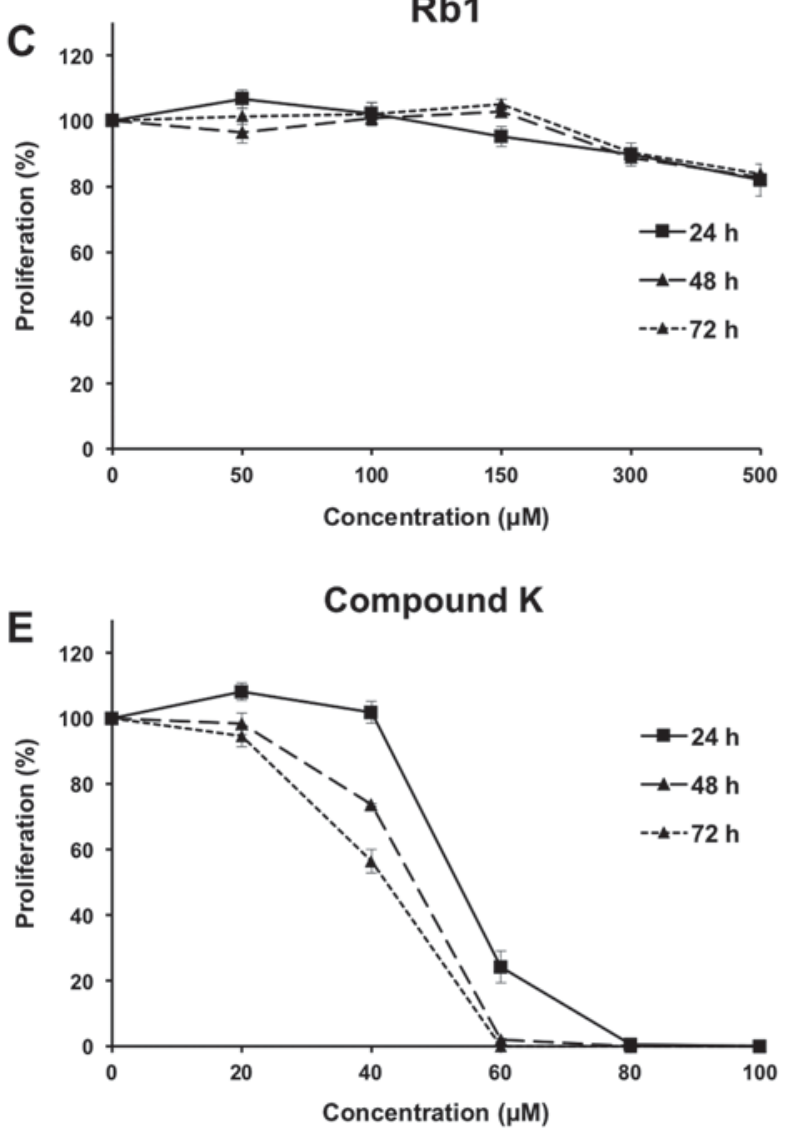

B HT-29
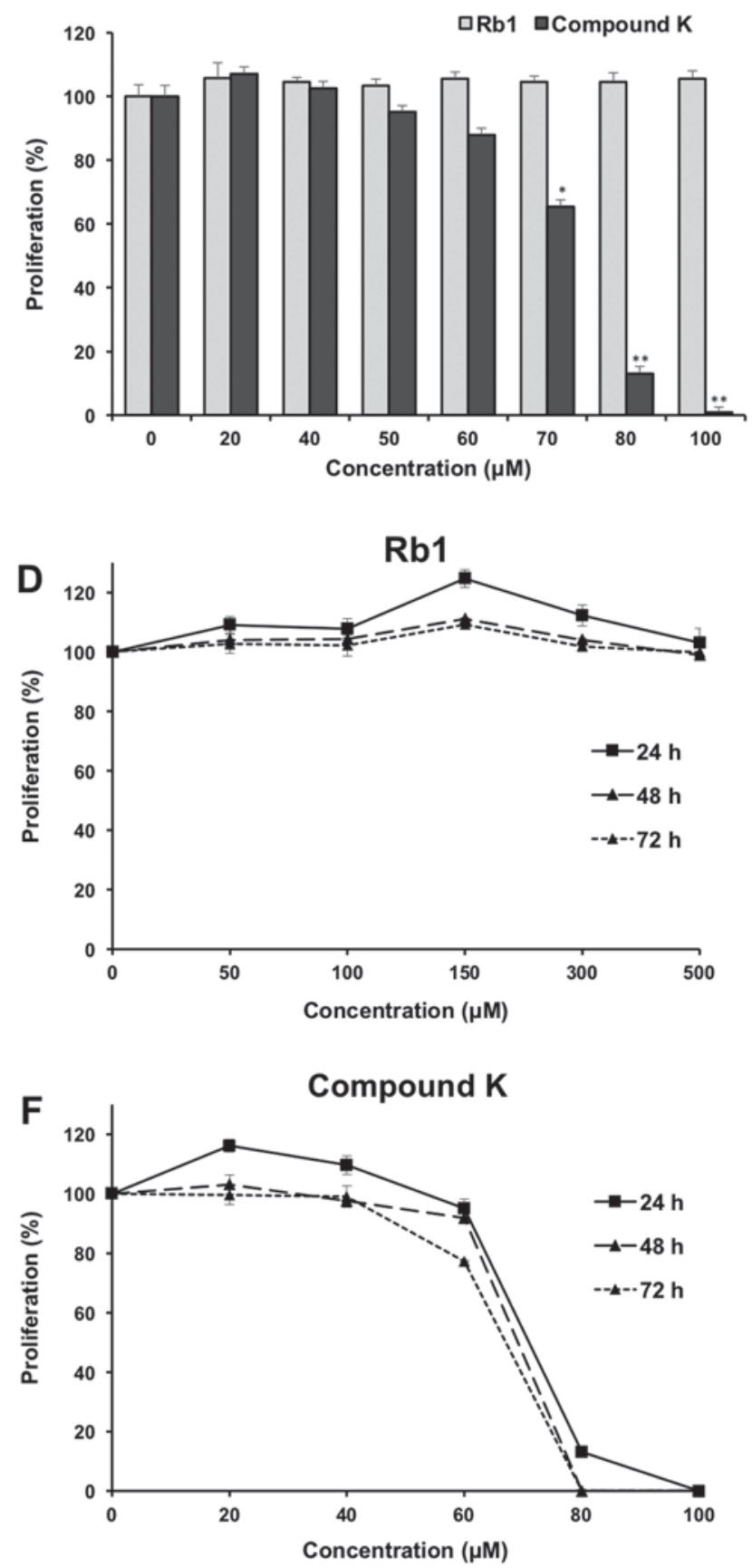

Figure 2. Effects of Rb1 and compound K on cell proliferation in HCT-116 and HT-29 human colorectal cancer cell lines. Concentration-associated antiproliferative effects of Rb1 and compound K on (A) HCT-116 cells and (B) HT-29 cells for 6 h. Time-associated antiproliferative effects of Rb1 on (C) HCT-116 cells and (D) HT-29 cells, and the counterpart of compound K on (E) HCT-116 cells and (F) HT-29 cells. ${ }^{*} \mathrm{P}<0.05$ and ${ }^{* *} \mathrm{P}<0.01$ vs. control $(0 \mu \mathrm{m})$.

compound $\mathrm{K}$ for $48 \mathrm{~h}$ increased the percentage of cells in the G1 phase to $58.33 \pm 1.19$ and $63.90 \pm 0.56 \%$, respectively, compared to $47.63 \pm 1.14 \%$ in vehicle-treated cells (all $\mathrm{P}<0.01$ ). Treatment of HT-29 cells with 60 and $70 \mu \mathrm{M}$ compound $\mathrm{K}$ for $48 \mathrm{~h}$ increased $\mathrm{G} 1$ phase cells to $55.67 \pm 0.71$ and $62.70 \pm 0.66 \%$ respectively, compared to $44.17 \pm 0.81 \%$ in vehicle-treated cells (all $\mathrm{P}<0.01$ ). Thus, in both cancer cell lines, compound $\mathrm{K}$ significantly increased the number of human colorectal cancer cells in G1 phase.

On the other hand, Rb1 treatment did not influence the cell cycle at 20 and $40 \mu \mathrm{M}$. These results suggested that compound
$\mathrm{K}$, the Rb1 metabolite, could significantly induce $\mathrm{G} 1$ phase cell cycle arrest in both HCT-116 and HT-29 cell lines.

Effects of Rbl and compound $K$ on cell apoptosis. The apoptotic effects of $\mathrm{Rb} 1$ and compound $\mathrm{K}$ were evaluated by flow cytometry after staining with Annexin V and PI. Annexin V can be detected in both early and late stages of apoptosis, whereas PI-stained cells only in late apoptosis or necrosis. Early apoptotic cells were positive for Annexin V and negative for PI (lower right quadrant); late apoptotic cells were stained for both Annexin V and PI (upper right quadrant). 


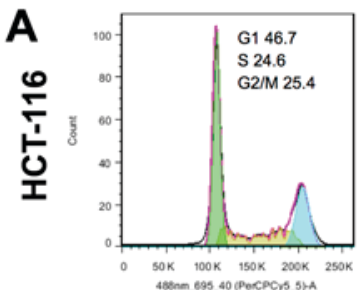

Control

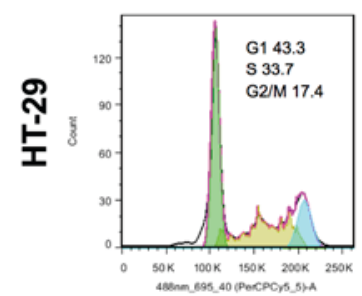

Control

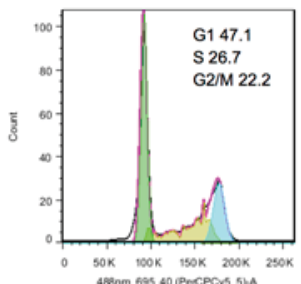

Rb1 $40 \mu \mathrm{M}$

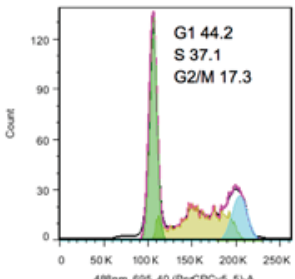

$\mathrm{Rb} 160 \mu \mathrm{M}$

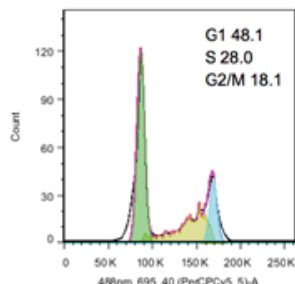

Rb1 $50 \mu \mathrm{M}$

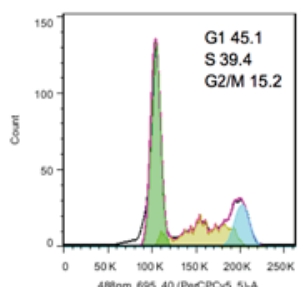

$\mathrm{Rb} 170 \mu \mathrm{M}$

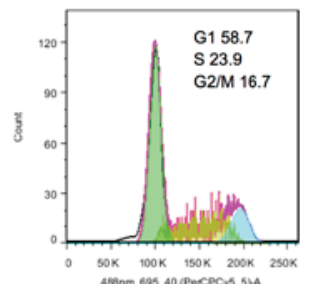

C-K $40 \mu \mathrm{M}$

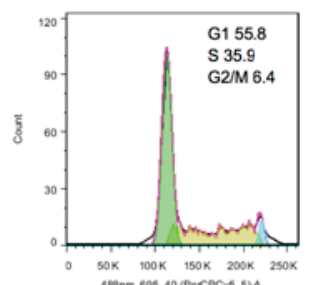

$\mathrm{C}-\mathrm{K} 60 \mu \mathrm{M}$

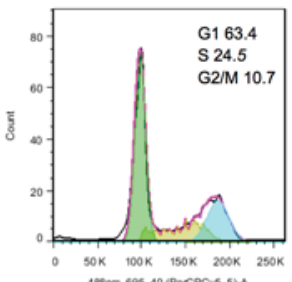

C-K $50 \mu \mathrm{M}$

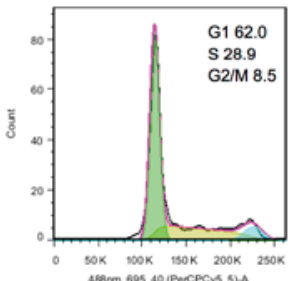

C-K $70 \mu \mathrm{M}$
B

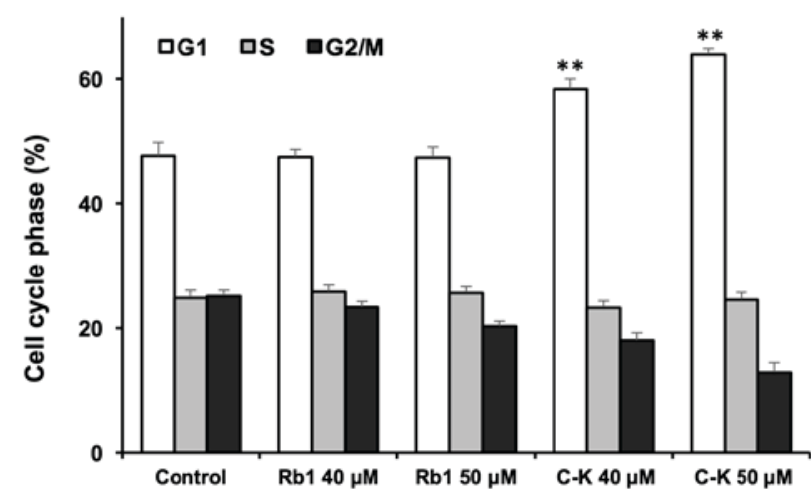

HT-29

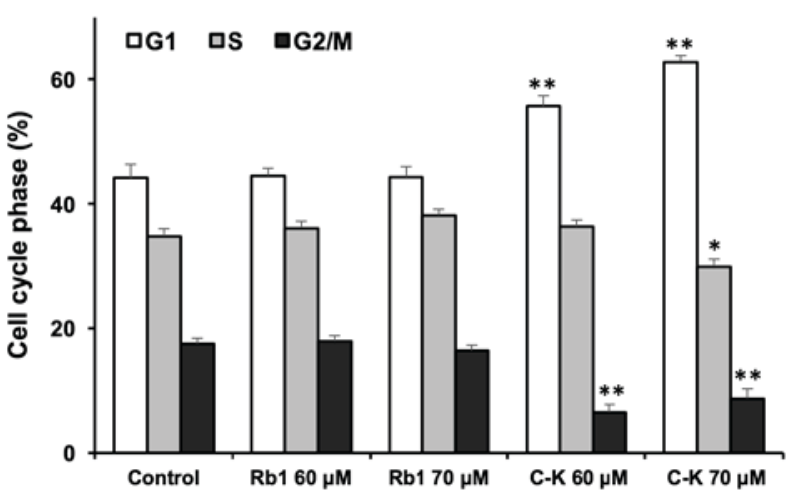

Figure 3. Cell cycle analysis of HCT-116 and HT-29 cells using flow cytometry. Following treatment with Rb1 or compound K for 48 h on HC-116 cells and Rb1 or compound $\mathrm{K}$ for $48 \mathrm{~h}$ on HT-29 cells, all of the colorectal cancer cells were stained with propidium iodide. (A) Typical cell cycle profiles and (B) interpretation of data. Data are presented as the mean \pm standard error of triplicate experiments. ${ }^{*} \mathrm{P}<0.05$ and ${ }^{* *} \mathrm{P}<0.01$, vs. control. $\mathrm{C}-\mathrm{K}$, compound $\mathrm{K}$.

As shown in Fig. 4, following treatment with $60 \mu \mathrm{M}$ of compound $\mathrm{K}$ for $48 \mathrm{~h}$, the percentage of early and late apoptotic HCT-116 cells was $46.85 \pm 1.37$ and $21.38 \pm 1.08 \%$, respectively (control, 6.54 \pm 1.28 and $2.12 \pm 1.17 \%$ ). When treated with $80 \mu \mathrm{M}$ compound $\mathrm{K}$ for $48 \mathrm{~h}$, the percentage of early and late apoptotic HT-29 cells was $50.69 \pm 1.20$ and $26.52 \pm 1.58 \%$, respectively (control: $4.02 \pm 1.21$ and $3.77 \pm 1.90 \%$ ). In contrast, Rb1 did not induce apoptosis with the same concentrations indicating that only compound $\mathrm{K}$ significantly induces cell apoptosis.

Effects of compound Kon cell cycle and apoptotic-related gene expression. To further explore the antiproliferative mechanisms, we evaluated the effects of compound $\mathrm{K}$ on selected cell cycle and apoptotic related genes. As shown in Fig. 5, compound $\mathrm{K}$ significantly up-regulated expression of p21 (CDKN1A), and downregulated the expressions of CDK6, cyclin D and cyclin E, which are G1 phase arrest regulators (Fig. 5A). In addition, compound $\mathrm{K}$ up-regulated the expressions of p53 and Bax, which are pro-apoptotic genes. In contrast, compound $\mathrm{K}$ downregulated the expression of $\mathrm{Bcl} 2$, which is an anti-apoptotic gene (Fig. 5B). Cell cycle and apoptotic related gene expression supported our observations with flow cytometry.
Effects of Rbl and compound K on inflammatory cytokine IL-8 secretion of colorectal cancer cell. LPS was used to induce HCT-116 and HT-29 cell lines to secrete the inflammatory cytokine IL-8. At the concentration of $100 \mathrm{ng} / \mathrm{ml}$, LPS did not show any significant influence on the cell growth of both cell lines (Fig. 6A and B). Induced by LPS, HT-29 cells can secrete IL-8 effectively and demonstrated a positive correlation with the induction time (Fig. 6D). However, the HCT-116 cell line showed a relatively limited IL-8 secretion level (Fig. 6C), so the HT-29 cell line was selected to conduct the further experimentation of anti-inflammatory evaluation (16).

As shown in Fig. 7, compound $\mathrm{K}$ significantly reduced the IL-8 production in HT-29 cells. When incubated with $20 \mu \mathrm{M}$ compound $\mathrm{K}$ of for 6 and $12 \mathrm{~h}$, the concentrations of IL- 8 were reduced from $180.33 \pm 4.32$ to $92.56 \pm 3.46$ and $70.05 \pm 2.32 \mathrm{pg} / \mathrm{ml}$ respectively $(\mathrm{P}<0.01)$ (Fig. $7 \mathrm{~B})$. In contrast, Rb1 did not show obvious anti-inflammatory effects on HT-29 cells (Fig. 7A).

\section{Discussion}

Colorectal cancer, one of the fourth leading causes of cancer-related death worldwide, is known to be a common 


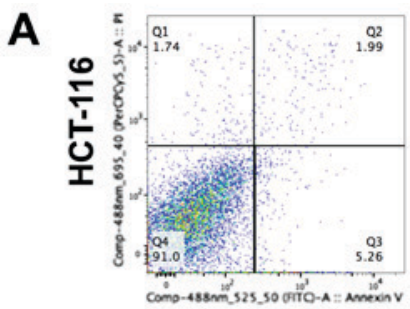

Control

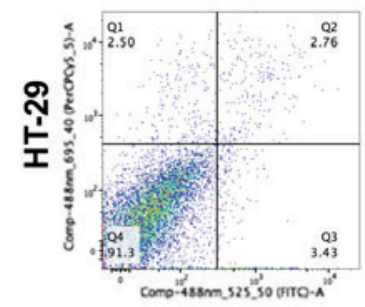

Control

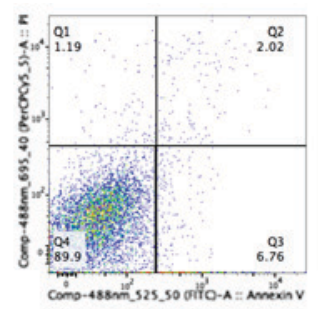

$\mathrm{Rb} 150 \mu \mathrm{M}$

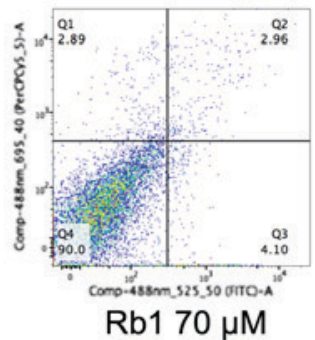

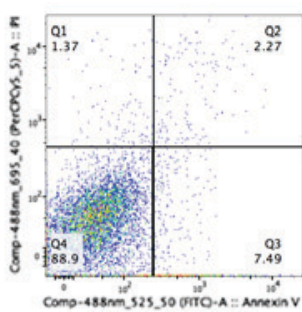

$\mathrm{Rb} 160 \mu \mathrm{M}$

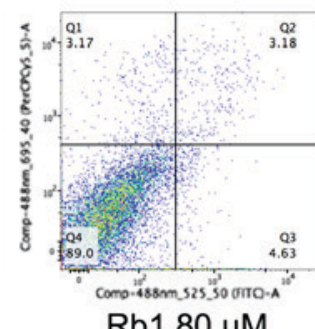

$\mathrm{Rb} 180 \mu \mathrm{M}$

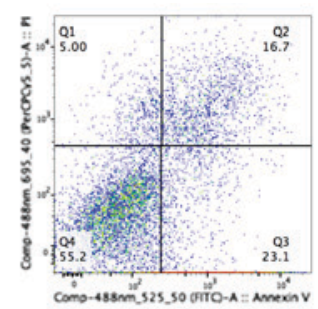

C-K $50 \mu \mathrm{M}$

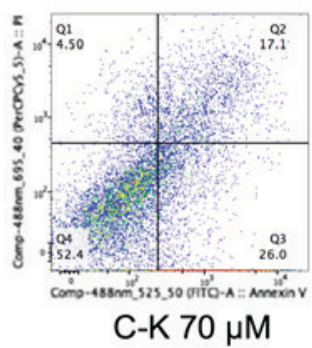

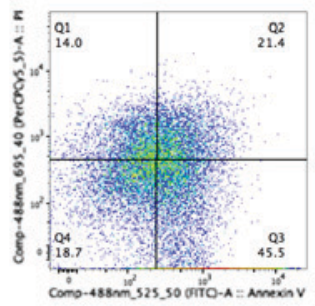

C-K $60 \mu \mathrm{M}$

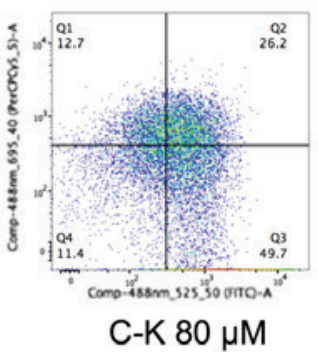

B

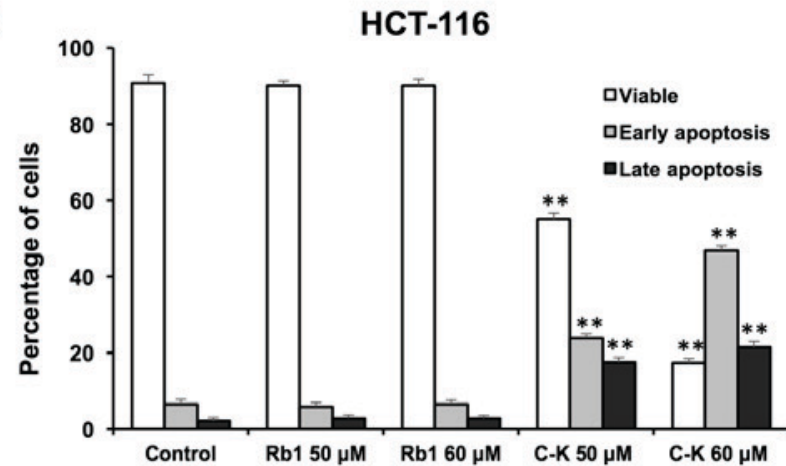

HT-29

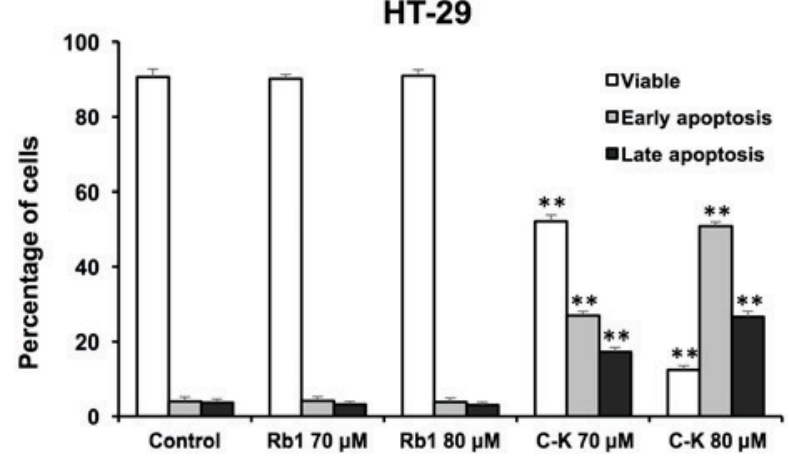

Figure 4. Apoptosis assay using flow cytometry following staining with Annexin V-fluorescein isothiocyanate/PI. HCT-116 and HT-29 cells were treated with $\mathrm{Rb} 1(40$ and $80 \mu \mathrm{M})$ and compound $\mathrm{K}$ for $48 \mathrm{~h}$. (A) Representative scatter plots of PI (y-axis) vs. Annexin V (x-axis). (B) Percentage of viable, early apoptotic and late apoptotic cells. Data are presented as the mean \pm standard error of triplicate experiments. ${ }^{* *} \mathrm{P}<0.01$ vs. control. PI, propidium iodide; $\mathrm{C}-\mathrm{K}$, compound $\mathrm{K}$.
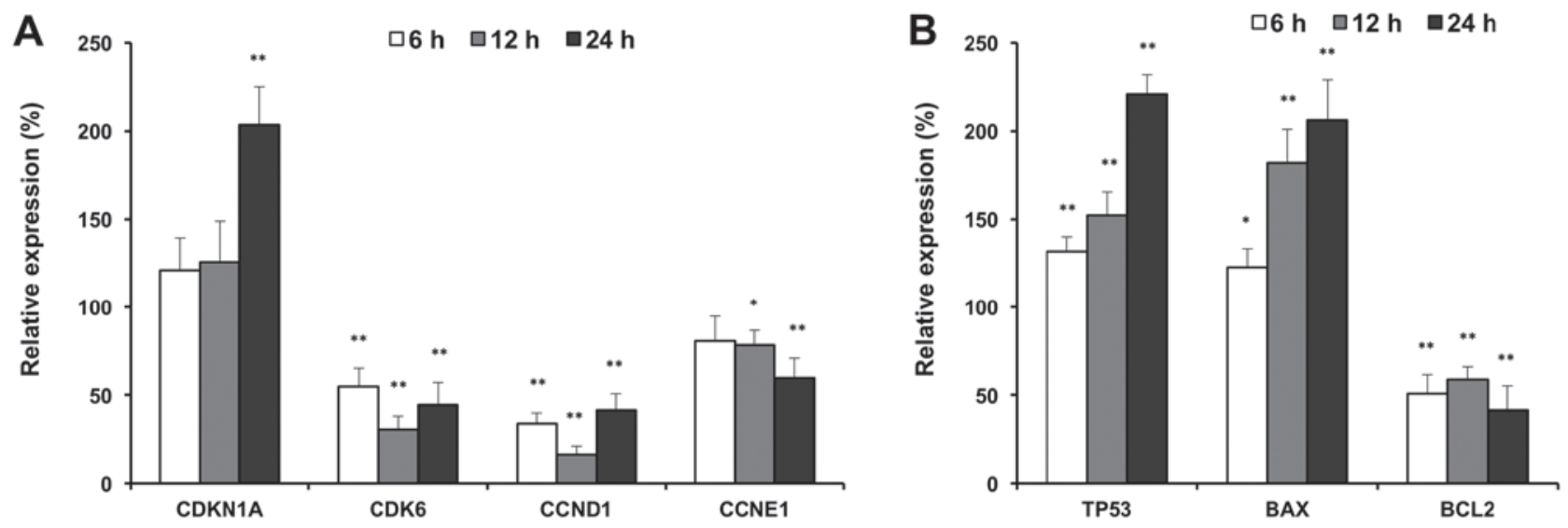

Figure 5. Reverse transcription-quantitative polymerase chain reaction analysis of cell cycle and apoptotic associated gene expression in HCT-116 cells. (A) Expressions of cell cycle associated genes. (B) Expressions of apoptotic associated genes. HCT-116 cells were treated with $30 \mu \mathrm{M}$ of compound K for 6, 12 and $24 \mathrm{~h}$. Data are presented as the mean \pm standard error of triplicate experiments. ${ }^{*} \mathrm{P}<0.05$ and $^{* * *} \mathrm{P}<0.01$ vs. control [a relative expression of $100 \%$ (at time $0 \mathrm{~h}$ ) was set as the control]. CDKN1A, cyclin dependent kinase inhibitor 1A or p21; CDK6, cyclin dependent kinase 6; CCND1, cyclin D1; CCNE1, cyclin E1; TP53, tumor protein 53 or p53; Bcl2, B-cell lymphoma 2; BAX, Bcl2-associated X protein.

malignant disease with a high mortality rate and gradually increased incidence (17-19). Colorectal cancer is a multifactorial disease involving genetic, environmental and lifestyle risk factors. In the development of colorectal cancer, chronic inflammation has been identified as a key predisposing factor $(20,21)$. The inflammatory state of the colon can strongly influence the process of colorectal cancer, and subtle inflammation in otherwise healthy colonic tissues may cause the conversion of a healthy colon into a dysplastic colon, as well (22). 
A
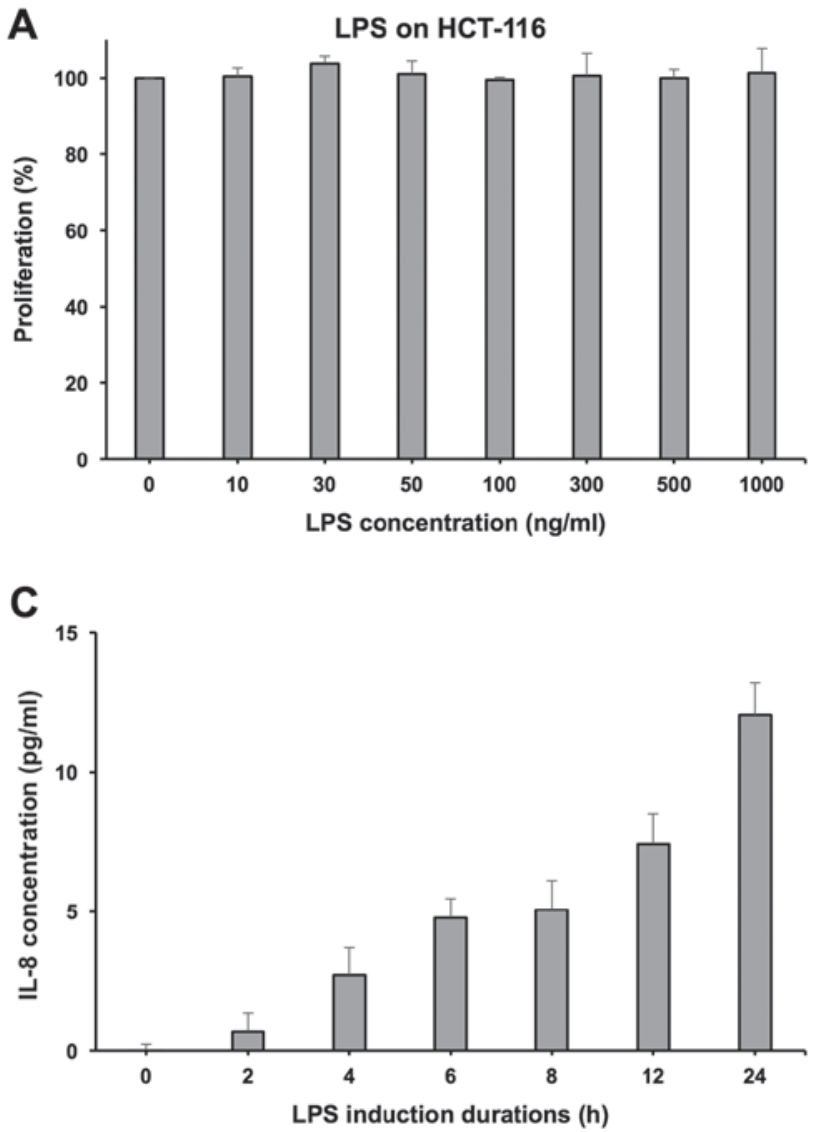

B

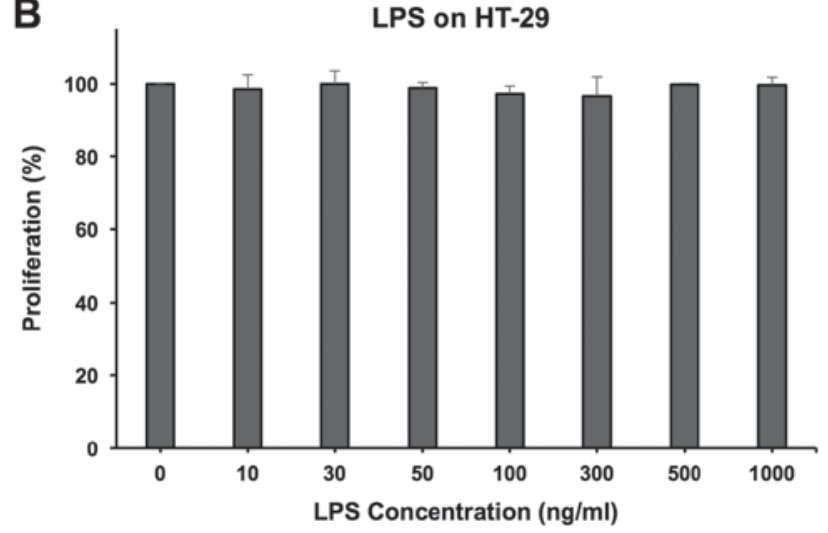

D

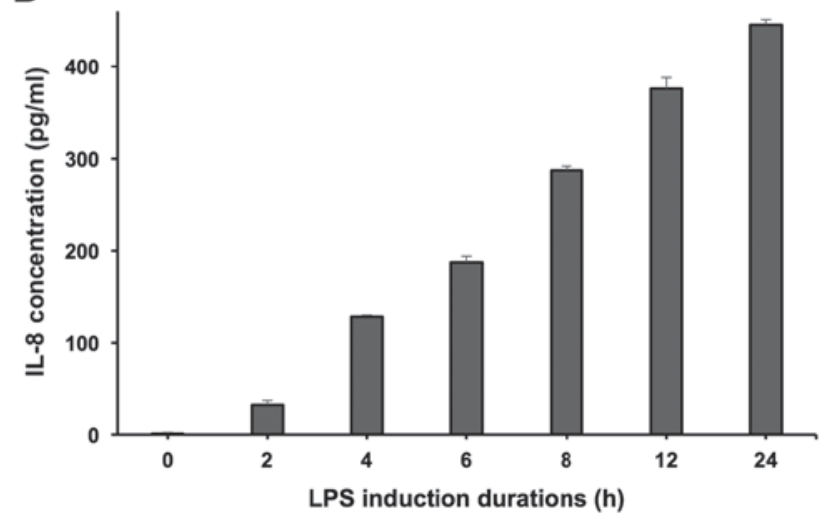

Figure 6. Experimental conditions using LPS to induce HT-29 cells to secrete IL-8. LPS exhibited no distinct anti-proliferation effects on (A) HCT-116 and (B) HT-29 cells with a 12-h incubation. The various induction durations of LPS (100 ng/ml) to induce IL-8 secretion on (C) HCT-116 and (D) HT-29 cells. LPS, lipopolysaccharide; IL, interleukin.

Due to the disadvantageous effects of chemotherapy, which may worsen the patient's quality of life prominently, it is necessary and meaningful to identify non-toxic chemicals extracted from herbal medicines for the treatment of colorectal cancer. In this study, HT-29 chemo-resistant cancer cells were used for the evaluation of the effects of compound $\mathrm{K}$.

Ginseng is one of the herbs that proved to be beneficial for the treatment. According to many studies, ginseng is active in maintaining health and effective in the prevention and treatment of cancers by different mechanisms (23-25). Ginseng is not only effective in reducing chemotherapy side effects and improving the quality of patient's life, it also plays a crucial role in inflammation reduction and thereby reduces the risk of cancer $(26,27)$. Ginsenoside Rb1 is a major component of American ginseng and Asian ginseng. The products of ginseng are almost always taken orally just like many other herbal medicines. After being ingested into the gut, ginsenoside $\mathrm{Rb} 1$ is degraded by intestinal microbiota and then stepwise converted into compound $\mathrm{K}$; this is a main metabolic pathway of $\mathrm{Rb} 1(28,29)$. As an important metabolite of Rb1, compound $\mathrm{K}$ could be absorbed into the systemic circulation and exert remarkable biofunctions $(30,31)$.

In this study, using LC-Q-TOF-MS, we examined the biotransformation of Rb1 by human gut microbiota, and compound $\mathrm{K}$ was identified as a main metabolite of $\mathrm{Rb} 1$. Compared with its parent compound Rbl, compound $\mathrm{K}$ shows a distinct anti-tumor effect in both HCT-116 and HT-29 cell lines. Compound K can also significantly arrest HCT-116 and HT-29 cells in the G1 phase, and induce cell apoptosis. In contrast, $\mathrm{Rb} 1$ did not exert any obvious influence on the cancer cell proliferation, cell cycle and apoptosis. RT-qPCR data supported our flow cytometry results, that compound $\mathrm{K}$ regulated the expressions of G1 phase cell cycle and apoptotic related genes.

We compared the anti-inflammatory effects of Rb1 and compound K using LPS to induce HCT-116 and HT-29 human colorectal cancer lines to secrete inflammatory cytokine IL-8. The IL-8 production indicates that the HT-29 cell line is a suitable in vitro model to evaluate the anti-inflammatory responses (16). Compound $\mathrm{K}$, the Rb1 metabolite, was observed to have significant anti-inflammatory effects, even at low concentrations, while Rb1 did not show any anti-inflammatory effects. Of note, the concentrations of compound $\mathrm{K}$ to be observed with anti-tumor effects are relatively higher than that for anti-inflammatory ones, which may imply that the compound $\mathrm{K}$ at low doses can play an anti-inflammatory role in the early stage of colorectal cancer with inflammatory conditions, and an anti-tumor role for high doses.

In conclusion, compound $\mathrm{K}$ is an important metabolite of $\mathrm{Rb} 1$ and possesses even more significant bio-functions compared with $\mathrm{Rb}$. Compound $\mathrm{K}$ can significantly induce G1 phase cell cycle arrest and apoptosis in both HCT-116 and HT-29 cell lines. Compound K can benefit the treatment of 

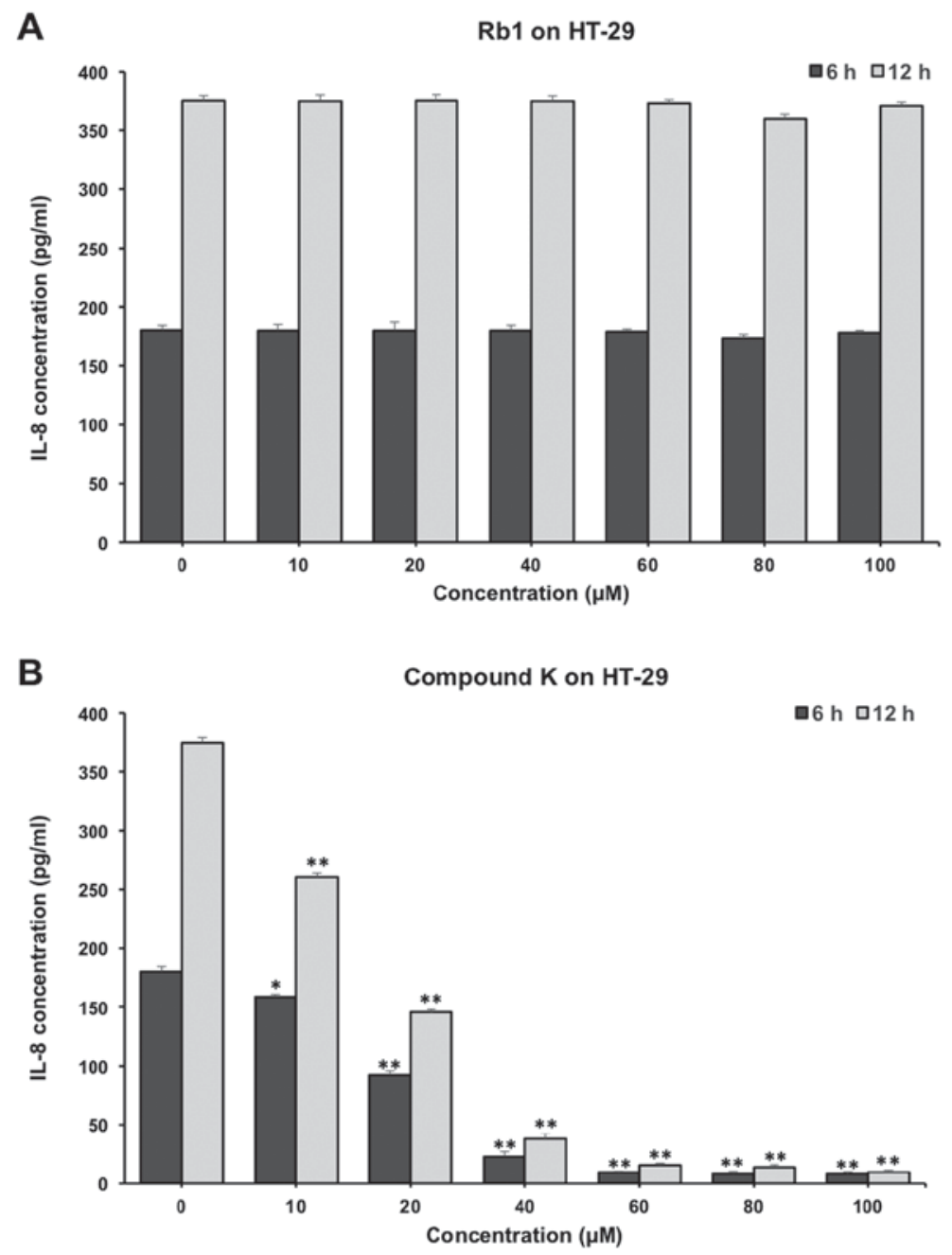

Figure 7. Effects of Rb1 and Compound $\mathrm{K}$ on inflammatory cytokine IL- 8 secretion in human colorectal cancer cell lines. The anti-inflammatory effects of (A) Rb1 and (B) compound K on HT-29 cells for 6 and $12 \mathrm{~h}$. ${ }^{*} \mathrm{P}<0.05$ and ${ }^{* *} \mathrm{P}<0.01$ vs. control $(0 \mu \mathrm{m})$. IL, interleukin.

cancer-associated inflammation and exert anticancer effects in a concentration related manner, using HT-29 cells. Future in vivo observations are needed to evaluate the clinical utility of compound $\mathrm{K}$ in colorectal cancer chemoprevention.

\section{Acknowledgements}

Not applicable.

\section{Funding}

The present study was supported in part by grants from China Postdoctoral Science Foundation (grant no. 2017M610830), National Natural Science Foundation of China (grant no. 81603378), Natural Science Foundation of Jiangsu Province (grant no. BK20160545) and The National Institutes of Health/National Center for Complementary and Integrative Health (grant nos. AT004418 and AT005362).

\section{Availability of data and materials}

All data generated or analyzed during the present study are included in this published article.

\section{Authors' contributions}

CY conceived the study and led the design of this research, and QW and $\mathrm{XN}$ made substantial contributions to the conception and design. HY, JW, CW and JZ made contributions to the acquisition of data. WH, CS and LL participated in the analysis and interpretation of data. HY and JW drafted the manuscript, CS revised it critically for important intellectual content, and CW gave final approval of the manuscript.

\section{Ethics approval and consent to participate}

The present study was approved by the Institutional Review Board at the University of Chicago; patients provided oral consent for sample collection.

\section{Consent for publication}

Not applicable.

\section{Competing interests}

The authors declare that they have no competing interests. 


\section{References}

1. Qi LW, Wang CZ and Yuan CS: Isolation and analysis of ginseng: Advances and challenges. Nat Prod Rep 28: 467-495, 2011.

2. Kim DH: Chemical Diversity of Panax ginseng, Panax quinquifolium, and Panax notoginseng. J Ginseng Res 36: 1-15, 2012.

3. Park J, Bui PTC, Song H, Kim SK, Rhee DK, Kim EY, Rhyu MR, Lee MS and Lee YJ: Ginseng on nuclear hormone receptors. Am J Chin Med 45: 1147-1156, 2017.

4. Yennurajalingam S, Tannir NM, Williams JL, Lu Z, Hess KR, Frisbee-Hume S, House HL, Lim ZD, Lim KH, Lopez G, et al: A double-blind, randomized, placebo-controlled trial of Panax ginseng for cancer-related fatigue in patients with advanced cancer. J Natl Compr Canc Netw 15: 1111-1120, 2017.

5. Wan JY, Huang WH, Zheng W, Park CW, Kim SH, Seo DB, Shin KS, Zeng JX, Yao H, Sava-Segal C, et al: Multiple effects of ginseng berry polysaccharides: Plasma cholesterol level reduction and enteric neoplasm prevention. Am J Chin Med 45: 1293-1307, 2017.

6. Qi LW, Wang CZ and Yuan CS: Ginsenosides from American ginseng: Chemical and pharmacological diversity. Phytochemistry 72: 689-699, 2011.

7. Yuan CS, Wang CZ, Wicks SM and Qi LW: Chemical and pharmacological studies of saponins with a focus on American ginseng. J Ginseng Res 34: 160-167, 2010.

8. Lee SJ, Ha N, Kim Y and Kim MG: Changes in the ginsenoside content during fermentation using an appliance for the preparation of red ginseng. Am J Chin Med 44: 1595-1606, 2016.

9. Du XH, Zhao YL, Yang DF, Liu Y, Fan K, Liang ZS and Han RL: A correlation model of UPLC fingerprints and anticoagulant activity for quality assessment of Panax notoginseng by hierarchical clustering analysis and multiple linear regression analysis. Anal Met 7: 2985-2992, 2015.

10. Wan JY, Liu P, Wang HY, Qi LW, Wang CZ, Li P and Yuan CS Biotransformation and metabolic profile of American ginseng saponins with human intestinal microflora by liquid chromatography quadrupole time-of-flight mass spectrometry. J Chromatogr A 1286: 83-92, 2013.

11. Xiao J, Chen H, Kang D, Shao Y, Shen B, Li X, Yin X, Zhu Z, Li H, Rao T, et al: Qualitatively and quantitatively investigating the regulation of intestinal microbiota on the metabolism of Panax notoginseng saponins. J Ethnopharmacol 194: 324-336, 2016.

12. Hu Z, Yang J, Cheng C, Huang Y, Du F, Wang F, Niu W, Xu F, Jiang R, Gao X and Li C: Combinatorial metabolism notably affects human systemic exposure to ginsenosides from orally administered extract of Panax notoginseng roots (Sanqi). Drug Metab Dispos 41: 1457-1469, 2013.

13. Wan JY, Wang CZ, Liu Z, Zhang QH, Musch MW, Bissonnette M, Chang EB, Li P, Qi LW and Yuan CS: Determination of American ginseng saponins and their metabolites in human plasma, urine and feces samples by liquid chromatography coupled with quadrupole time-of-flight mass spectrometry. J Chromatogr B Analyt Technol Biomed Life Sci 1015-1016: 62-73, 2016.

14. Wang CZ, Kim KE, Du GJ, Qi LW, Wen XD, Li P, Bauer BA, Bissonnette MB, Musch MW, Chang EB and Yuan CS: Ultra-performance liquid chromatography and time-of-flight mass spectrometry analysis of ginsenoside metabolites in human plasma. Am J Chin Med 39: 1161-1171, 2011.

15. Wang CZ, Du GJ, Zhang Z, Wen XD, Calway T, Zhen Z, Musch MW, Bissonnette M, Chang EB and Yuan CS: Ginsenoside compound $\mathrm{K}$, not $\mathrm{Rb} 1$, possesses potential chemopreventive activities in human colorectal cancer. Int J Oncol 40: 1970-1976, 2012.

16. Grimoud J, Durand H, de Souza S, Monsan P, Ouarné F, Theodorou $\mathrm{V}$ and Rogues $\mathrm{C}$ : In vitro screening of probiotics and synbiotics according to anti-inflammatory and anti-proliferative effects. Int J Food Microbiol 144: 42-50, 2010.
17. Ferlay J, Soerjomataram I, Dikshit R, Eser S, Mathers C, Rebelo M, Parkin DM, Forman D and Bray F: Cancer incidence and mortality worldwide: Sources, methods and major patterns in GLOBOCAN 2012. Int J Cancer 136: E359-E386, 2015.

18. Troeung L, Sodhi-Berry N, Martini A, Malacova E, Ee H, O'Leary P, Lansdorp-Vogelaar I and Preen DB: Increasing incidence of colorectal cancer in adolescents and young adults aged 15-39 years in Western Australia 1982-2007: Examination of colonoscopy history. Front Public Health 5: 179, 2017.

19. Campos FGCM, Figueiredo MN, Monteiro M, Nahas SC and Cecconello I: Incidence of colorectal cancer in young patients. Rev Col Bras Cir 44: 208-215, 2017 (In English, Portuguese).

20. Ullman TA and Itzkowitz SH: Prognosis of colorectal cancer in inflammatory bowel disease: Data from a state registry. Dig Dis Sci 62: 1850-1851, 2017.

21. Ehrlich AC,PatelS, Meillier A, Rothstein RD and Friedenberg FK: Chemoprevention of colorectal cancer in inflammatory bowel disease. Expert Rev Anticancer Ther 17: 247-255, 2017.

22. Brennan CA and Garrett WS: Gut microbiota, inflammation, and colorectal cancer. Annu Rev Microbiol 70: 395-411, 2016.

23. Wang CZ, Huang WH, Zhang CF, Wan JY, Wang Y, Yu C, Williams S, He TC, Du W, Musch MW, et al: Role of intestinal microbiome in American ginseng-mediated colon cancer protection in high fat diet-fed AOM/DSS mice. Clin Transl Oncol 20: 302-312, 2018.

24. Dai D, Zhang CF, Williams S, Yuan CS and Wang CZ: Ginseng on cancer: Potential role in modulating inflammation-mediated angiogenesis. Am J Chin Med 45: 13-22, 2017.

25. Kim HS, Kim MK, Lee M, Kwon BS, Suh DH and Song YS: Effect of red ginseng on genotoxicity and health-related quality of life after adjuvant chemotherapy in patients with epithelial ovarian cancer: A randomized, double blind, placebo-controlled trial. Nutrients 9: pii: E772, 2017.

26. Yu T, Rhee MH, Lee J, Kim SH, Yang Y, Kim HG, Kim Y, Kim C, Kwak YS, Kim JH and Cho JY: Ginsenoside Rc from Korean red ginseng (Panax ginseng C.A. Meyer) attenuates inflammatory symptoms of gastritis, hepatitis and arthritis. Am J Chin Med 44: 595-615, 2016.

27. Poudyal D, Le PM, Davis T, Hofseth AB, Chumanevich A, Chumanevich AA, Wargovich MJ, Nagarkatti M, Nagarkatti PS, Windust A and Hofseth LJ: A hexane fraction of American ginseng suppresses mouse colitis and associated colon cancer: Anti-inflammatory and proapoptotic mechanisms. Cancer Prev Res (Phila) 5: 685-696, 2012.

28. Tawab MA, Bahr U, Karas M, Wurglics $M$ and Schubert-Zsilavecz M: Degradation of ginsenosides in humans after oral administration. Drug Metab Dispos 31: 1065-1071, 2003.

29. Kim KA, Jung IH, Park SH, Ahn YT, Huh CS and Kim DH: Comparative analysis of the gut microbiota in people with different levels of ginsenoside Rb1 degradation to compound $\mathrm{K}$. PLoS One 8: e62409, 2013.

30. Xiao J, Chen D, Lin XX, Peng SF, Xiao MF, Huang WH, Wang YC, Peng JB, Zhang W, Ouyang DS and Chen Y: Screening of drug metabolizing enzymes for the ginsenoside compound $\mathrm{K}$ in vitro: An efficient anti-cancer substance originating from Panax ginseng. PLoS One 11: e0147183, 2016.

31. Chen Y,Xu Y,Zhu Y and Li X: Anti-cancer effects of ginsenoside compound $\mathrm{K}$ on pediatric acute myeloid leukemia cells. Cancer Cell Int 13: 24, 2013.

This work is licensed under a Creative Commons Attribution-NonCommercial-NoDerivatives 4.0 International (CC BY-NC-ND 4.0) License. 